\title{
The growth share matrix as a planning tool: caveats and practical problems
}

\author{
C.G. Robinson \\ Graduate School of Business Administration, University of the Witwatersrand, Johannesburg
}

Limitations exist on the naive application of the growth share and growth gain matrices as resource allocation techniques. This, the last in a series of three articles, points out some considerations essential for successful application of the Boston Consulting Group's approach to setting strategy. Thirteen caveats ranging from the breakdown of the implicit correlations between cash flows and market share and market growth rate through motivational and political probiems must condition a competent analysis. Practical problems in implementing portfolio planning are highlighted.

S. Afr. J. Bus. Mgmt. 1986, 17: $31-37$

Daar bestaan sekere beperkinge op die naïewe toepassing van die groei-aandeel- en groei-toename-matrikse as hulpbron-toedelingstegnieke. In hierdie artikel, die laaste in 'n reeks van drie artikels, word sekere aspekte wat wesenlik is vir die suksesvolle toepassing van die Boston Groep se benadering tot strategieformulering aangewys. Dertien voorbehoude wat met versigtigheid gehanteer moet word vir die bekwame uitvoering van 'n analise, word bespreek. Hulle strek vanaf die opsplitsing van implisiete korrelasies tussen kontantvloei en markaandeel en markgroeisyfer tot by motiverings- en politieke probleme. Die praktiese probleme by die toepassing van portefeuljebeplanning word bespreek. S.Afr. Tydskr. Bedryfsl. 1986, 17: $31-37$

\section{C.G. Robinson}

Graduate School of Business Administration, University of the Witwatersrand, Johannesburg, P.O. Box 31170, Braamfontein,

\section{Some applications considerations}

Limitations exist on the naive application of the growth share matrix. The matrix depends on the relationship between cash flow and the two variables, relative market share and market growth rate. There are 13 mitigating factors that must be borne in mind before the cash flow characteristics of the strategic menagerie can be applied slavishly.

Market share may not be correlated with cash flow The relationship between market share and cash flow may be very weak owing to a number of factors (Abell \& Hammond, 1979);

- Experience effects may be very small. For some reason or other an experience curve may not exist in a given business (Cvar, 1980 and Robinson, 1982). The experience curve is not a law of nature and hence, before it can be used as a fundamental underlying assumption in planning it may be wise to check for the existence of an experience curve for a given business.

- Value added may be low. For low levels of value added the impact of an experience effect on competitive cost differentials may be negligible.

- A competitor may have access to a low cost source of input materials unrelated to his relative share position. The competitive edge may not be correlated with relative market share, but with a different set of criteria such as access to franchises, technology and so on.

- Low market share producers may be on steeper curves than the high market share competitors owing to superior production technology. This is the case in the ferrochrome industry where small manufacturers with the latest generation of technology can have a competitive cost edge and hence better profits and cash flows than larger older competitors.

- Differences in experience may have little impact on costs because innovations in production technology are easily and swiftly adopted by all competitors. This occurs when the major suppliers of original equipment provide the technology and advances in an industry.

- Capacity utilization rates may differ, thus affecting costs and cash flow. The PIMS programme (Schoeffler, Buzzell \& Heany, 1974 and Roberts, 1981) and experience both indicate that low levels of capacity utilization are unprofitable and hence not attractive as cash generators.

- Strategic factors other than relative market share may affect profit margins. Cash flow may be strongly dependent on patents, product quality or other forms of competitive differences. 
If retative marke share and cash flow are not correlated this has the effect of collapsing one of the dimensions of the growth share matrix and effectivety leaves only one variable, marke growth rate, as a basis for taking strategic decisions. This may tend to imply that under the circumstances a portfolio approach based on a detailed product life cycle analysis may be more useful than one based on the growth share matrix.

Relationship between market growth rate and cash flow may be weak.

The growth share marrix is precticared on the assumptions that high rates of growth consume cash to fund fixed and working capital requirements, and that maturity of the life cycle brings about the genesis of profits. This may be incorrect owing to a number of factors (Abell \& Hammond, 1979);

- Capital intensity may be low. If fixed and working capital imensity is low, for example in an indent agency, it may be possible to increase the size of the business substantially whout requiring a meaningful increase in either fixed or working capital. It may be possible to grow the business by the mere addition of a typewriter and a telex machine without draining cash.

- High entry barriers may exist. Margins may be sustainable and large enough to produce positive cash flows and to finance growth at the same time. Technology, patent, and wher forms of protection could etect entry barriers (Porter, 1980).

- Indusary overcapacity and price competition may depress prices in maturity. Price competition may depress margins in maturity because of industry overcapacity or dumping. Even though financing neods may decline, cash flow can deteriorate.

- Legal restrictions may limit profitability. Levels of profitability may be either legislated or allocated at the whim of government agencies with the result that cash flows do not improve on maturity.

- Seasonal and cyclical patterns may produce short-run imbalances in profitability and cash flow. Seasonal effects can be fett on cash flow. More cogently, as economies move into recession, businesses redefine their markets, and sometimes large firms move downmarket with a domino effect on those companies below them.

\section{The problem of market definition}

If the market is incorrectly identified it makes the measurement of market share and market growth rate unreliable and lends to erroneous strategies. Market definition errors can depend on a number of incorrect assessments including the incorrect assessment of market boundaries based on faulty geographic, demographic, psychographic, behavioural, competitor, and other variables.

- In Figure 1 the impact of an error in geographic segmentation is shown (Channon \& Jalland, 1979). When measured in terms of the UK market, company A has a clear position of retative dominance against its nearest competitors. When measured in the context of the total EEC market the company's business is transformed from an apparent cash generator to being a dog. Channon \& Jalland (1979) pointed out that despite the fact that the European market leader did not compete in the UK market at all, the implied threat of potential entry was significant enough to reduce the cash flow of company A's business as the prices it charged were affected by the position in western Europe as a whole.
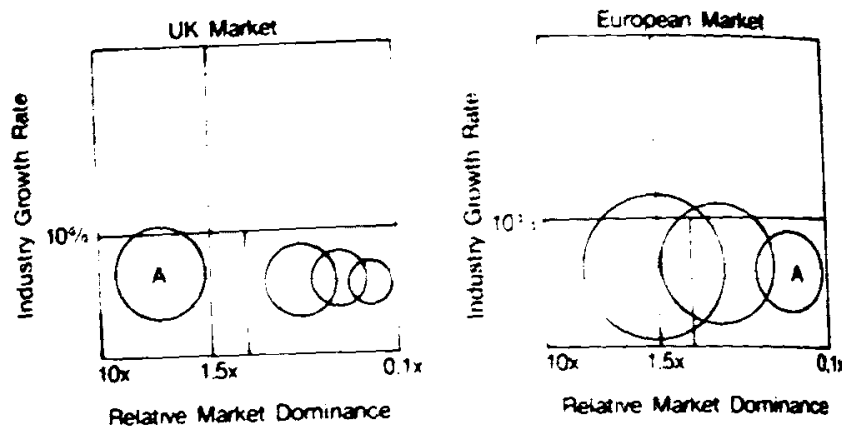

Figure 1 The importance of geographic market definition in pontiotio analysis (Channon \& Jalland, 1979:110)

The level of market segmentation affects the positioning Markets can be segmented at different levets from the very broad to the very precise. Although the focus is on strategic positioning, the level of segmentation still effects the position of a business on the grid.

- In Figure 2 a company's positioning on the grid is shown as a major distributor of records, music cassettes, and cartridges (Channon \& Jalland, 1979). The market is shown as a high growth market. In fact, the market should really be segmented into three types of records - popular, classical and budget - and into cassettes and cartridges. This reveak very different positions for the individual business units in terms of market share and growth rate. Decisions made on the basis of the first positioning could be in serious etror in the light of more careful segmentation. Channon \& Jalland pointed out that care must be taken in distinguishing between strategic market segmentation and product differentiation. Otherwise, undefendable segments may be incorrectly identified.
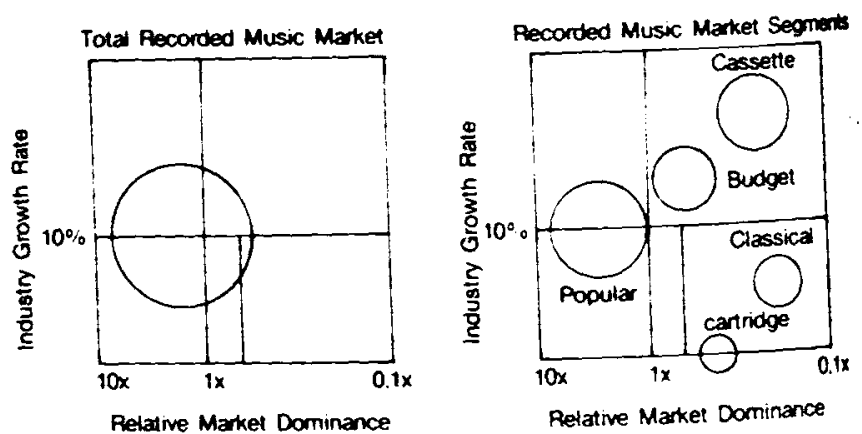

Figure 2 The importance of market segment identification in portfolio analysis (Channon \& Jalland, 1979:111)

\section{Inflation clouds the picture}

High rates of inflation have a serious effect on the measure ment of market growth rate and on the cash flow and profit characteristics of any business.

- Firstly market growth rate should be stated in unit terms to remove the impact of inflation. This is not always possible in practice and because industries inflate at different rates the choice of the correct sectoral deflator can be a problem. - Secondly, under conditions of inflation, price and cost changes affect businesses in different ways and can lead to the repositioning of businesses on the grid. Figure 3 shows the different chemical business units of a company under deflated and undeflated market conditions (Channon \& Jalland, 1979). A general impact of inflation is to make low real growth businesses into apparent high growth 
businesses. Few businessmen, when considering historic company performance, are likely to deflate the data. It is a sobering exercise.

Under conditions of high inflation, growth rates in money terms grow rapidly. Working capital requirements associated with funding a given level of business in unit terms can escalate rapidly and turn cash generators into cash users. The effect is not uniform and in the example given in Figure 3 , a significant change in the structure can take place with the relative positioning of a number of the businesses changing markedly.
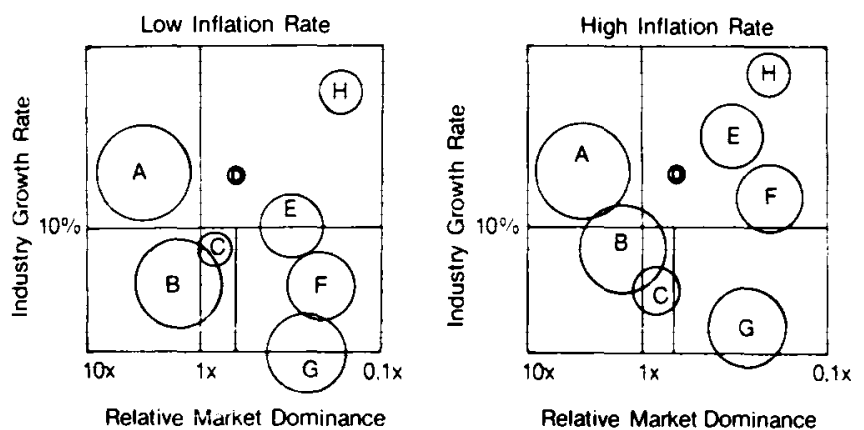

Figure 3 The differential effect of inflation on the strategic portfolio (Channon \& Jalland, 1979:112)

- Thirdly, depreciation allowances may be quite inadequate to cope with the costs of replacing capital assets (Channon \& Jalland, 1979). In capital intensive businesses high rates of inflation can seriously transform the actual cash flow characteristics of a theoretically balanced portfolio and result in a dangerous liquidity position.

- Fourthly, under inflationary conditions most businesses become cash traps. This may be true even if they show an accounting profit (Channon, 1981). A typical manufacturing company in a low growth environment must earn around $7 \%$ on sales or the entire company becomes a cash trap. High growth sectors and capital intensive businesses require even higher margins. At lower growth rates the increase in assets required to maintain business will exceed the reported profit. The company runs the danger of being locked into a real cash trap which is worthless as it may never pay out dividends and could need continual cash injections.

- Finally the growth gain matrix has its centre of gravity for a balanced portfolio substantially changed by inflation as shown in Figure 4. Under high rates of inflation interest rates tend to move up to reflect the economic imbalance. Market growth and business growth rates may well remain unchanged or even decline. This tends to reinforce the wellknown effect of gearing going negative and cash flows can actually reverse unless margins can be increased to compensate for the higher debt burden. In addition the maximum sustainable growth rate for the portfolio, as calculated from:

$g=\frac{D}{E}(r-i) p+r p$

will change if $i$ rises faster than $r$, thus giving rise to a portfolio imbalance as portrayed in Figure 4.

\section{Foreign exchange variations cause problems}

Multinationals and industries in which it is strategically naive to set strategy on a limited geographic basis must contend with the effects of foreign exchange variations. Foreign ex-

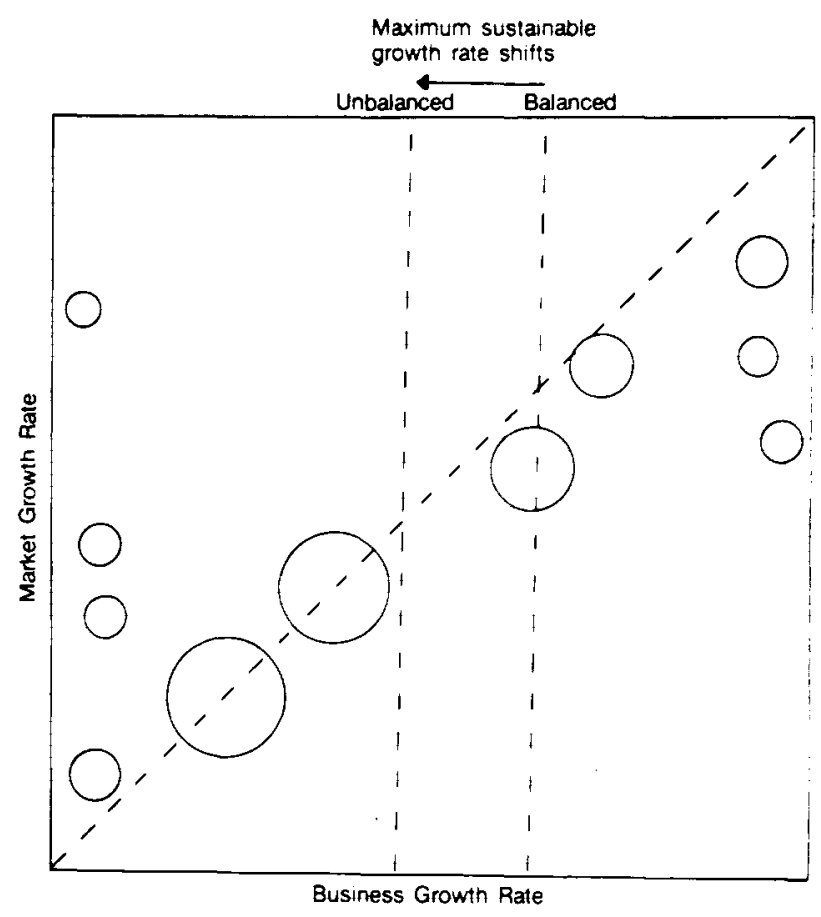

Figure 4 The impact of inflation on portfolio balance and the maximum sustainable growth rate

change variations can totally transform the relative experience curve effect (Channon \& Jalland, 1979:113 and Robinson, 1982:49). When costs are measured in a weaker currency the slope of the experience curve may reverse and a real cost increase could take place. This implies that market share and relative costs may cease to be correlated. There is a mitigating effect in that economies subject to high rates of inflation are those with a poor exchange rate performance and the effects of inflation and foreign exchange rate variations can cancel one another out.

Free floating does not always occur and government intervention in foreign exchange markets must affect costs, profits and cash flow.

- The cash flow and the return on investment characteristics of a business can be affected by the currency in which assets and profits are measured. So, for example, Channon points out that US and other US-quoted multinationals have found SEC-imposed changes in accounting treatments of overseas assets and earnings have significantly affected their balance sheets when measured in dollars (Channon \& Jalland, 1979: 113). Multinationals operating production assets in strong currency environments and supplying weak currency areas, where margins are reduced owing to the exchange rate differential, report decreased returns, increases in relative capital intensity, and decreased cash flows.

- An added strategic effect is felt by some large European multinationals which have the policy of not allowing overseas subsidiaries to become independent SBU's until a required return is earned on production assets resident in the parent country. Only after a given return on assets is achieved is strategic independence granted. An embryonic SBU could find a decade elapse before being granted independence as exchange rates move downward at the same rate, or faster, than profits move upward.

- Multinational transactions can change the relative economics of a business. Centralization of multinational treasury functions has occurred in order to optimize group cash flow and post-tax profitability and to minimize foreign exchange exposure. A number of multinationals are actively managing 
their foreign exchange positions as profit centres generating up to $50 \%$ of corporate profitability (Channon \& Jalland, 1979.114).

The strategic planning criteria may therefore not be pretax cash flow but the amount, location, and currency of posttax income.

\section{Other planning criteria may exist.}

The growth share and growth gain matrices are predicated upon the sustaining of growth of a portfolio from internally generated cash flows. Other planning criteria may be more valid. Criteria such as:

- capitalizing on tax benefits,

- the use of paper to fund growth via high premiums on market value to book value of common stock, and

- the use of paper to fund acquisitions,

Under these circumstances the planning mode becomes tax avoidance, equity generation or acquisition rather than the balancing of sustainable cash flows and the allocation of cash resources among opportunities.

Organization structure rarely reflects the strategic business units.

Significant problems occur in practice, particularly in implementing a portfolio strategy:

- Firsty, the strategic business units of a corporation rarely conform to the formal organization structure (Channon \& Jalland, 1979 and Haspeslagh, 1982). The organization's structure is often a relic of history or a vehicle designed around operating control, or other, considerations. It is therefore possible to find subelements of strategic business unit located in a number of functional product or geographic divisions of a firm, particularly if the firm is a multinational. Two tendencies exist:

- One is to assess the corporate portfolio in terms of the formal organization structure rather than to get involved in the problems of accounting separately for crossdivisional businesses.

- The second is not to realize the fact that parts of a formal division may not in fact belong to the same strategic business unit and to continue to treat them as belonging together.

Odd aberrations can and do transpire (Channon \& Jalland, 1979:114). Seriously dysfunctional behaviour occurred in a major European chemical producer when one half of a high growth business was located in a product division identified by top management as a cash-generating operation whilst the other half was located in a regional geographic division singled out for heavy investment. In the first case the business unit management were reluctant to make any investment which did not show an extremely high rate of retum, rapid payback and low cash usage whereas in the second, managers were prepared to accept low rates of retum provided an investment contributed to improving the business growth and share position (Channon \& Jalland, 1979). Consequently the managers responsible for operating pans of the same business within the different divisions were attempting to pursue almost totally different strategies.

To guard against such situations it is necessary to restructure the organization on an ongoing basis dependent on the identification of strategic business units. Major reorganizations are usually painful and have to be introduced against the wishes of vested interests within the existing structure. Significant reorganization does not occur in an evolutionary manner but takes place periodically when it becomes clear that strategy and structure have diverged significantly. The portfolio planning models are used as a guide for strategic cash flow allocation and may provide little or no help concerning organization design.

\section{Cash control systems may not exist}

The use of a resource allocation grid based on expected cash flows presumes that the company is able to reallocate the cash flows from various businesses in the portfolio. Surprisingly, however, companies are unable to reallocate cash flows around the matrix because:

- In many organizations the traditional profit centre concept exists. This frequently means that a profit centre, because it is profitable and has surplus cash, is able to reinvest its free cash flow frequently in mature businesses. This leads to overinvestment in businesses at the top of the product life cycle and does not lead to cash allocation around the matrix. A major canning company, amongst the best in the world, was encouraged to reinvest in mature, and dying, product lines owing to the profit centre concept and to neglect emerging businesses. As result money was reinvested in areas such as peaches in syrup, even though emerging consumer tastes required either reinvestment in other food lines or, at least, product line enhancement with the effort being focused on peaches in natural juice to suit emergent consumer tastes.

- A diversified building materials, engineering and construx. tion company was a clear cash-generating business. It produced cash from a depleting asset and was allowed to reinvest these funds in overseas acquisitions rather than being forced to redeploy them to the organizations' developing activities in construction and engineering (Channon \& Jalland, 1979). This was made possible by the fact that central management allowed divisional cash management and high investment discretion levels.

Successful redeployment of cash resources requires a central resource allocation, or banking function, both for strategic investments and the allocation of cash. This may require central banking accounts, global or regional cash pools, and capital charge items on managed assets.

\section{Transfer pricing clouds the picture}

A very real problem exists with regard to transfer pricing.

It is possible to show an accounting profit wherever it is most desirable dependent on the manipulation of transfer prices. This raises two issues:

- Firstly, it may be preferable to manipulate profits to maximize after-tax returns. Transfer prices may be manipulated to provide profits as, where, and when needed to maximize after-tax returns.

- Secondly, transfer pricing may be used to validate a managerial position, and to provide profits where none should exist, in order to satisfy managerial ego as to the credibility of previous decision-making.

\section{The problem of overhead costs}

The joint overhead cost allocation problem is a vexing one for a number of reasons.

- Firstly, in integrated companies with product lines which are often intimately related the allocation of overhead costs is often a thorny problem. Profits, and cash flow, are subject to the whim of the accountant. A further complicating factor is the fact that frequently accounting systems do not exist in the organization to facilitate the allocation of costs and profits to various strategic business units. This is a direct 
result of three factors;

One: Costs and profits are often monitored on an absorption rather than a direct costing basis.

Two: Strategic business units frequently bear no relationship to the organization structure and to the accounting systems adopted.

Three: Problems arise with regard to the sharing of overhead facilities and, by implication, experience effects.

\section{Motivational problems occur}

When a business is identified as a cash generator or a dog to be placed in a harvest or divest category, motivational and other problems may occur.

Most organizations, particularly in non-socialist economies, have a common value system endorsing growth as normal for all businesses. The decision to run down a business leads to problems with managers, the work-force and the consuming public.

- When a business is identified as one to be run down or eliminated from a portfolio it is often difficult to get acceptance of this fact from the managers concerned. This may partly be due to the fact that some businesses may be investments in managerial ego but may also be due to the reality that businessmen are not uninvolved in their decisions. Executives have made anguished comment to the author: 'How do you kill your own children?' The acceptance that a business is to be run down is alien to accepted management values.

Conventional logic requires that if a business is to be run down it should be a gradual process and that the management style to be adopted should be conservative paternalistic and cost conscious. Contact with businessmen may imply the opposite. As one entrepreneur quoted 'if I want to run a business down give me a twenty five year old frustrated dynamo. He'll maximise cash flow and close the business down in one year instead of ten'.

- The harvest position is soon identified by the work-force who tend to become demotivated and resistant to management policies (Channon \& Jalland, 1979). Industrial relations problems often accumulate in a bid to maintain job security. In some economies it is becoming increasingly difficult to shed labour in a casual manner. Strong pressure may be mounted for reinvestment in the cash-generating business. This can be the exact reverse of central managements's intended strategy.

- The conventional wisdom associated with the strategic harvesting and disinvestment of a business implies that a business may be quietly run down and milked for cash. Experience implies that this may not be so. When a business is being disinvested it generates signals that the consuming public picks up - for example discount sales on lines soon to be obsolete. Rather than being quietly milked of cash the reality may be that the business collapses like a pricked soufflé as consumers, distributors and users excercise other options in the expectation of collapse (Channon \& Jalland, 1979).

- Motivational problems exist particularly in youthful conglomerates where the whole empire has been built on the acquisition of smaller companies founded by $a$, now middleaged, entrepreneur. How is it possible to get the enthusiasm and endorsement of an entrepreneur in running down his original brainchild to create cash for other opportunities? in dominant business companies where one core activity has constituted the major profit earning potential (Channon \& Jalland, 1979). In these cases the business unit management resents being asked to pass on the cash to new businesses in which they do not see the logic. The existing business is also in a far more powerful situation to press its case having been the principal profit earner. In such companies the central management team has also frequently been promoted from the dominant profit earner and is frequently unsure about the potential of the new businessess. When in doubt cash is redeployed into the existing, often mature, profit centre.

\section{Practical problems with portfolio planning}

Management cannot afford the leisure of divorcing theory from practice. A theory only becomes useful when it meets administrative reality.

- Lip service is frequently paid to portfolio planning and chief executive officers frequently refer, almost knowledgeably, to cash cows, dogs and so on while continuing to reinvest in mature markets and to allow profit centres to retain profits. The challenge of portfolio planning should, once adopted, become the rule of the prince and implementation should become the responsibility of the chief executive officer.

- It takes time for companies to adopt and integrate portfolio planning into their systems. Haspeslagh (1982) identified three stages namely:

(i) portfolio grid analysis

(ii) corporate agreement on missions, and

(iii) explicit negotiation of missions with SBU managers.

The average time taken for a company to move from the first grid to explicit assignment and negotiation of all missions with the business unit managers appears to take about five years (Figure 5).

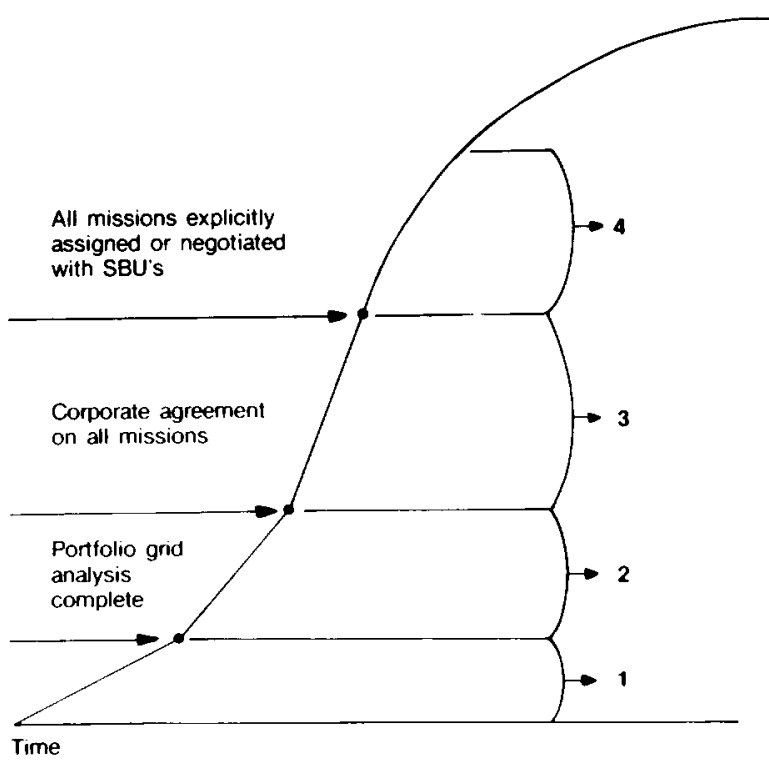

Stage 1 New Portfolio Planning: Having just introduced the approach. companies are still in the process of constructing the portfolio

Stage 2 Undecided Portfolio Planning: The initial grid completed, the companies have not yet decided at the corporate level what to do with the businesses or which strategic missions to assign to the SBU's

Stage 3 Unassigned Portfolio Planning: Corporate level decisions are reached on the strategic mission for each business unit. but companies hold no explicit negotiations yet with the unit managers

Stage 4 Process Pontfolio Planning: Portfolio planning is a central part of the ongoing management process as evidenced by the explicit negotiation of strategic missions with SBU managers.

Figure 5 Stages of introduction of process portfolio planning (Haspeslagh, 1982:63) 
- Portfolio planning is a multilevel activity. When analysing the corporate portfolio and making trade-offs among businesses, corporate management looks at the company in aggregate. In this broader context the company tends to look at SBU's that are frequently organizational units and to assign to the units strategic missions to reflect the cash flow contribution of the whole company.

Individual businesses then get involved in a repetition of the same process but at a far more detailed level of disaggregation. The strategic businesses identified are more likely to result from an analysis of individual business areas rather than from an attempt ot accommodate the existing organization structure. The SBU missions thus defined, reflect the particular strategy the company wishes a business unit manager to follow in each competitive arena.

Figure 6 illustrates this concept. A corporate level analysis has identified a division, or subsidiary, of the total corporation as an emerging cash cow. A detailed business level analysis of the cash cow identifies four different strategic business units each requiring a different strategic mission. At this stage the question must be asked and indeed reflected back to corporate headquarters that if the decision is taken to run the business as a cash cow then product line $x$, a wildcat, must be reconsidered in terms of its potential impact on the cash-generation characteristics of the subsidiary. The subsidiary cannot be a cash generator and easily fund business $x$.

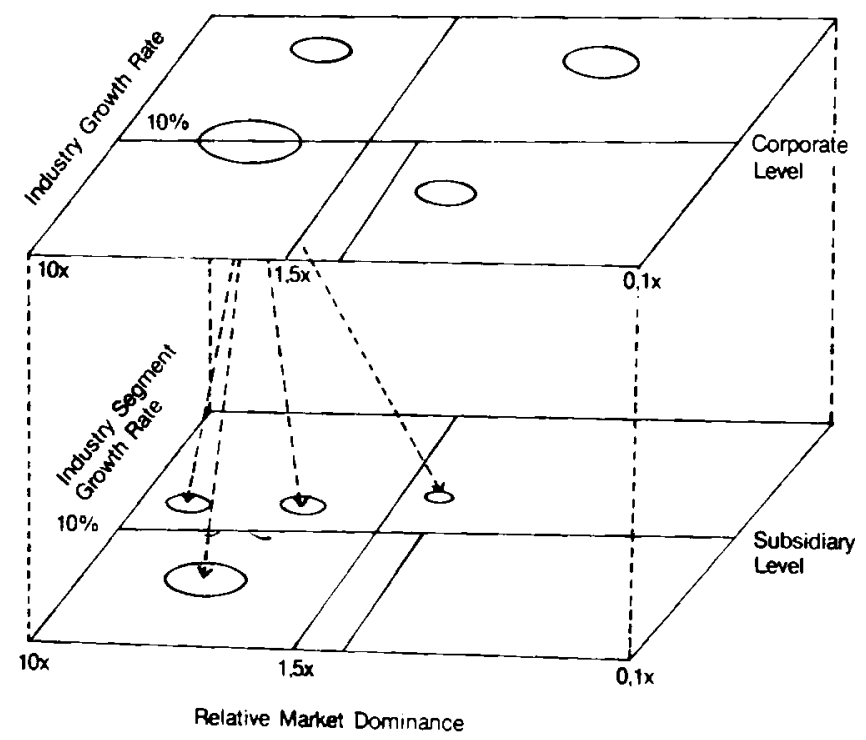

Figure 6 Multilevel portfolio planning

- The definition of the strategic business units evolves throughout the introduction of the process. As companies go through more planning cycles the SBU's become more of a formal organizational reality and the segment definition becomes better.

- Nasty problems are created by the problems of strategic interdependence. At its simplest the cash flow and profitability of an SBU is easily manipulated by transfer pricing policies on products transferred from one SBU to another. A more thorny question arises in the case of shared experience via shared manufacturing facilities, common basic technology, or common distribution channels.

With many differing dimensions trade-offs have to be made (Haspeslagh, 1982). The guiding principle appears to be that a company should define the SBU to include those resources that will be the key strategic variables in the future. This predicates a knowledge of the corporate vision at this early stage or at least a multiple pass operation achieved by planning and replanning or competent ongoing planning

Haspeslagh (1982) indicated that a number of companies surveyed made these trade-offs in practice with a bias towards cost efficiency in relation to responsiveness. The business economics and experience-based orientation of portfolio planning must tend to push cost structures as a basis for business definition. As a result companies may tend to define SBU's along technological and manufacturing rather than market lines. Because the SBU responsiveness to local market and other influences is difficult to quantify, companies may find that their world-wide SBU's may be less responsive to local issues and cooler towards international activities than under previous structures and planning approaches (Haspeslagh, 1982).

In low value added businesses, such as service industries and reseller industries, the implication could be that SBU definition may be more validly based on market criteria rather than on technology or cost criteria dependent on an experience curve.

- Shared experience, in which experience gains from a related technology causes costs to drop below those of competitors with a background only in a single technology, can turm a new entrant with a small market share into a strong cash generator (Hammond \& Allan, 1975). 'Texas Instruments' explosive domination of the consumer electronic calculator market over established but more specialised competitors such as Bowmar Instruments is a classic example.' The key to Texas Instruments' success was its shared experience in integrated circuit manufacture.

- The Boston Consulting Group's approach relates to a longterm decision-making horizon. It is not a technique for making short-term adjustments to business portfolios. It is recommended (Hammond \& Allan, 1975 and Abell \& Hammond, 1979) that a five-year horizon be considered minimal, except for products in which five years represents a substantial part of the product life cycle. Blow hot, blow cold strategic commitment by management will probably lead to disappointing outcomes. It may be necessary to be content with mediocre short-run performance in quest of the final goal of a balanced portfolio. If short-term decreases in earnings patterns are likely to dissuade management they should be advised not to embark on the strategy in the first place.

\section{Conclusion}

The Boston Consulting Group attempts to address the re source allocation problem via a number of techniques. The conceptual bases underlying the primary planning matrix, the growth share matrix, are the concepts of the experience curve and the product life cycle. The idea is to optimize the benefits associated with relative market share, and hence the business' competitive cost position, and the impact of the growth rate of the market, a surrogate variable for position on the product life cycle. The basis for resource allocation is the expected cash flow characteristics of businesses on the BCG grid.

- cash cows are cash generators, they require an invest to hold strategy while maximizing cash flow,

- stars are potential cash cows which require adequate funding to establish a dominant position before market growth rate slows down and they change into cows,

- wildcats, question marks, or problem children have neither market share nor growth on their side. They are poorly 
positioned in growing markets and need funding to become stars. If resources are inadequate it is suggested that withdrawal take place,

- dogs are neither cash generators, nor in many instances cash drains, they can be left alone or if necessary be removed from the portfolio.

The maximum sustainable rate of growth for a portfolio can be calculated and used to assess the portfolio's ability to sustain growth from internally generated sources.

Comparisons can be made using the growth gain matrix to assess both the relative growth rate of businesses against the industry average and to check the portfolio for balance.

Frontier curves can be used to highlight growth areas, cash generators and money traps. Lines of equally attractive opportunities can be used to make investment decisions.

The overall effect is to give a set of guidelines for setting competitive strategy based on:

- a balanced portfolio of businesses;

- an analysis of portfolio trends;

- an evaluation of competitors' portfolios; and

- the development of target portfolios.

Very real reservations must be made in connection with the naive application of the techniques suggested, particularly because

- relative market share may not be correlated with cash flow;

- market growth rate may not be strongly negatively correlated with cash flow;

- it is difficult to define the market;

- levels of market segmentation affect the positioning of businesses;

- inflation clouds the picture;

- foreign exchange variations cause problems;

- other planning criteria, such as tax considerations may be more valid;

- the organization structure rarely reflects the strategic business units concerned;

- cash control systems frequently do not exist in companies;

- transfer pricing clouds the picture;

- the joint overhead cost allocation problem and its attendant accounting procedures is a headache;

- motivational problems occur; and

- status and politics interfere.
These reservations imply that a number of practical considerations must be borne in mind,

- lip service may be all that is paid;

- it takes time to adapt and adopt portfolio planning systems;

- portfolio planning is a multilevel activity with levels of aggregation;

- the correct definition of the SBU may take time to evolve;

- strategic interdependence causes problems;

- shared experience effects must be identified; and

- the focus is long term and peripatetic planning is not aposite. The benefits claimed are that the approach

- helps to reappraise SBU objectives realistically;

- gives guidelines on the optimum financial structure;

- aids the resource allocation process;

- avoids minimum rate of return, or hurdle rate, calculations in which the assumptions are manipulated;

- avoids strategic traps and investments in managerial ego;

- gives guidelines for growth;

- gives guidelines for contraction or harvesting; and

- helps pinpoint the black holes of finance.

\section{References}

Abell, D.F. \& Hammond, J.S. 1979. Strategic market planning. Englewood Cliffs. Prentice Hall.

Channon, D.F. July 1981. Strategic management in inflationary conditions. Pretoria. Lecture series, University of South Africa.

Channon, D.F. \& Jalland, M. 1979. Multinational strategic planning. London, MacMillan.

Cvar, M. 1980. Strategic planning: What is it? Cambridge, Massachusetts, Strategic Planning Institute.

Day, G.S. 1977. Diagnosing the product portfolio. J. Market. vol. $41,29-38$

Hammond, J.S. \& Allen, G.B. 1975. A note on the Boston Consulting Group concept of competitive analysis and corporate strategy. Boston, Massachusetts. Harvard Business School, note $9-175-175$.

Haspeslagh, P. January, February 1982. Portfolio planning: uses and limits. Harv. Bus. Rev., p. 58-71.

Porter, M. 1980. Competitive strategy. The free Press, New York.

Roberts, K. 1981. The profit assessment report. Cambridge. The Strategic Planning Institute.

Robinson, C.G. 1982. Experience curves as a planning tool. University of South Africa. Working paper, School of Business Leadership.

Schoeffler, S., Buzzell, R.D. \& Heany, D.F. March, April, 1974. Impact of strategic planning on profit performance. Harv. Bus. Rev., 137-145. 